\begin{abstract}
"Mircea cel Batran" Naval Academy Scientific Bulletin, Volume XX - 2017 - Issue 1
The journal is indexed in: PROQUEST / DOAJ / Crossref / EBSCOhost / INDEX COPERNICUS I DRJI / OAJI I

JOURNAL INDEX / I2OR / SCIENCE LIBRARY INDEX / Google Scholar / Academic Keys/ ROAD Open Access I Academic Resources / Scientific Indexing Services / SCIPIO / JIFACTOR
\end{abstract}

\title{
GRAIN SEABORNE TRADE SHIPOWNERS STRATEGIES
}

\author{
Romeo BOSNEAGU ${ }^{1}$ \\ Vlad BORDANC ${ }^{2}$ \\ Bogdan SOCOLIUC ${ }^{3}$ \\ ${ }^{1}$ PhD Navigation and Naval Management, Mircea cel Batran Naval Academy Constanta, Email: \\ romeo bosneagu@yahoo.com \\ ${ }^{2} \mathrm{MSc}$, Mircea cel Batran Naval Academy Constanta \\ ${ }^{3}$ Master Student, Mircea cel Batran Naval Academy Constanta
}

\begin{abstract}
Grains are, as bulk cargo, included in the major dry bulk category along with iron ore and coal. The shipping principles demonstrate that the trend in seaborne trade on this segment of the bulk market is dictated by the relation between the supply available from the producing countries and the demand in the main importing regions. This relation is strongly influenced by the seasonal conditions which determines the quantities transported on the main shipping routes to vary. All of this makes freight rate to fluctuate along with the ratio of shipping demand and supply per time. This relationship defines the characteristics of the market in terms of structure, the number of companies providing transport services, scale of their operations, fleet size. Various studies conducted in this regard have concluded that this market activity is conducted in such manner as it can be considered a "perfect competition". In these conditions the ship owners and operators develop their strategies based on statistical analyzes related to the temporal evolution of grain production, and forecasting trends for the entire shipping system analyzed.

Keywords: dry bulk shipping market, grain seaborne trade, shipowner strategies
\end{abstract}

\section{Introduction}

Transports represents the "circulation of entire economic system". The national economy of a country and global economy in general cannot be defined outside the transportation framework. These services ensures a good activity in the main two economic sectors - primary (agriculture, silviculture, aquaculture) and secondary (industry, constructions), but also in other services of tertiary sector (fast-moving consumer goods, human migration, exchange of information, services, etc.). With its diversity, technical level, velocity and flux energy, transports facilitates the following: the bond between regions with raw materials and the ones which process goods; redistribution of products, goods and services to population; free movement of people; exchange of information; the approximation between settlements, countries and continents (Bosneagu, 2017).

The role of maritime transportation is to ensure the dynamics, fast-moving consumer goods, exchange of primary matter, free movement of people etc., thus being a different economic activity, which "makes money" not by "producing" or "processing" goods but by "spatial movement of goods produced by other economic activities, including information and free movement of people" (Vlasceanu et al, 2004).

Maritime transportation opened early a door to accomplishing some important aspects which are related to humankind evolution, such as: it helped developing worldwide economy; it made possible

DOI: 10.21279/1454-864X-17-I1-004

(c) 2017. This work is licensed under the Creative Commons Attribution-Noncommercial-Share Alike 4.0 License. to exit from isolation of human settlements; integration in general information systems; the growth of cultural and civilisation levels. This type of activity kept the track with the requirements growth due to modernisation and an increase in traffic and volume of traded goods.

The seaborne trade of dry cargo is actually one of the most efficient types, especially regarding the cost-efficient of volume of goods handled. Ships are mainly operated in tramp regime, while the value of freight and transport contractual clauses varies frequently and are subject to negotiation depending on the market conditions.

The maritime transportation of dry cargo market is a resultant of other four different markets: those of freight and commercial transaction, where transport contracts can be found; the market of ships construction; the market of second-hand ships and the market of vessels sold for scrap (Lun et al, 2010). The essence of this mechanism and the evolution of such market is defined by the fluctuation of the other four markets and it also follows the impact of those on the market which is studied.

"Major bulks" category includes grains, goods, ore and coal. The exchange of those with regard to economic and physical trade is atypical because ore and coal comes from industrial economic systems whose production can be planned ahead. Apart from this type of goods, the total production and yield of these two market structures - supply and demand (Lorange, 2005). Moreover, there is a correlation which is frequently made between the main countries 


\section{"Mircea cel Batran" Naval Academy Scientific Bulletin, Volume XX - 2017 - Issue 1 \\ The journal is indexed in: PROQUEST / DOAJ / Crossref / EBSCOhost / INDEX COPERNICUS / DRJI / OAJI I \\ JOURNAL INDEX / I2OR / SCIENCE LIBRARY INDEX / Google Scholar / Academic Keys/ ROAD Open Access I Academic Resources / Scientific Indexing Services / SCIPIO / JIFACTOR}

which produce grain and their maritime transportation routes. It is known that with grain it is a difficulty to make a correct prevision of available quantities in export regions with regard to available tonnage on the market.

The commerce with agriculture products have recorded a continuous growth because of the high demand from emerging economy regions. The value of agriculture global exports has almost tripled between 2000 and 2012, while their volume has raised with approximately $60 \%$ during the same period. With these figures in mind, it is most probable that the global demand of agriculture products will remain high in the following decades (FAO, 2016).

At the moment China is an important grain producer, with almost $18 \%$ of global production, which is used just for local consumption. Beside this figure, due to the fact that the demand is very high, China is the biggest grain products importer with approximately $8 \%$ of the global production, depending especially on its internal production value.

Beside China the biggest grain products importers are: Japan, Egypt, Europe, Saudi Arabia, South Korea and Iran. China, Japan and South Korea usually import from Australia, Canada, United States of America, Argentina and Brazil. The transport, because of the important quantity imported and long distances, is made with bulk carriers (Supramax or Panamax type). In some other cases are used Capesize bulk carriers or Handysize bulk carriers in Australia or West Canada routes. Egypt and other countries from North Africa (Marocco and Algeria etc.) are importing grains mainly from Ukraine and Russian Federation or other European countries like France. These transports are usually made with smaller ships, for example Supramax, Handysize types or other smaller coastal ships. This resembles the grain import in Europe from Ukraine, Russia or other countries, but it is not available for imports made in United States of America and East Canada where are used Supramax and Handysize bulk carriers. Other countries like Iran, Saudi Arabia and other Arab countries from Gulf are important importers of grains from South America, Argentina, Brazil or Australia. On these routes are usually used Supramax or Capesize bulk carriers.

Usually, ports from U.S.A., Canada, Australia and Europe have more strict standards regarding how old a ship which carries grains can be allowed to enter in a port, thus resulting in many ships which not comply with those regulations to be kept out of ports and finally the freight value can be higher on these three continents.

\section{Methodology}

This article expresses an opinion regarding usual commercial strategies applied in maritime grain transport which are elaborated based on scientific research, process, analysis and interpretation of data statistics.

The analysis of historical data statistics about maritime grain/wheat transport based on regions brings into spotlight the fact that Western Europe and Japan were the principal importer regions starting from 1960 to 1980s. When former communist countries in Eastern Europe entered into market, a growth in demand was registered which dated close to year 2005 when it began a downfall of imports to these two principal regions. Moreover, the demand of grains to Middle East and Africa has become an influential factor on the market, precisely in the mechanism of supply and demand balance (Stopford, 2009). During 2006 2013 (2013 is the last year when official statistics were made at the FAO level) production, demand and maritime transportation of grains have registered a continuous growth.

The procentual analysis of the main geographic export and import cereal regions for year 2013 appears like this (table 1 and graph 1, 2, 3, 4): U.S.A., E.U., Canada and a big part of South America are the main export regions while Asia, South America, Africa and Middle East are the main importer regions.

Table 1 Main geographic distribution on regions on a global scale regarding export/import of grain

\begin{tabular}{|l|c|c|c|c|}
\hline & \multicolumn{2}{|c|}{$\begin{array}{c}\text { Geographic } \\
\text { cereal export } \\
\text { distribution }\end{array}$} & \multicolumn{2}{c|}{$\begin{array}{c}\text { Geographic } \\
\text { cereal import } \\
\text { distribution }\end{array}$} \\
\hline & $\mathbf{2 0 1 0}$ & $\mathbf{2 0 1 1}$ & $\mathbf{2 0 1 0}$ & $\mathbf{2 0 1 1}$ \\
\hline USA & $33 \%$ & $36 \%$ & & \\
\hline Asia & & & $31 \%$ & $33 \%$ \\
\hline EU & $10 \%$ & $12 \%$ & & \\
\hline $\begin{array}{l}\text { South } \\
\text { America }\end{array}$ & & & $22 \%$ & $21 \%$ \\
\hline Africa & & & $22 \%$ & $22 \%$ \\
\hline $\begin{array}{l}\text { Middle } \\
\text { East }\end{array}$ & & & $18 \%$ & $15 \%$ \\
\hline Argentina & $8 \%$ & $11 \%$ & & \\
\hline Australia & $8 \%$ & $10 \%$ & & \\
\hline Canada & $9 \%$ & $9 \%$ & & \\
\hline Europe & & & $5 \%$ & $6 \%$ \\
\hline CSI & & & $2 \%$ & $3 \%$ \\
\hline Others & $32 \%$ & $22 \%$ & & \\
\hline
\end{tabular}

Graph 1 Geographic grain export distribution 2010 
"Mircea cel Batran" Naval Academy Scientific Bulletin, Volume XX - 2017 - Issue 1 The journal is indexed in: PROQUEST / DOAJ / Crossref / EBSCOhost / INDEX COPERNICUS / DRJI / OAJI I JOURNAL INDEX I I2OR / SCIENCE LIBRARY INDEX / Google Scholar / Academic Keys/ ROAD Open Access I Academic Resources / Scientific Indexing Services / SCIPIO / JIFACTOR

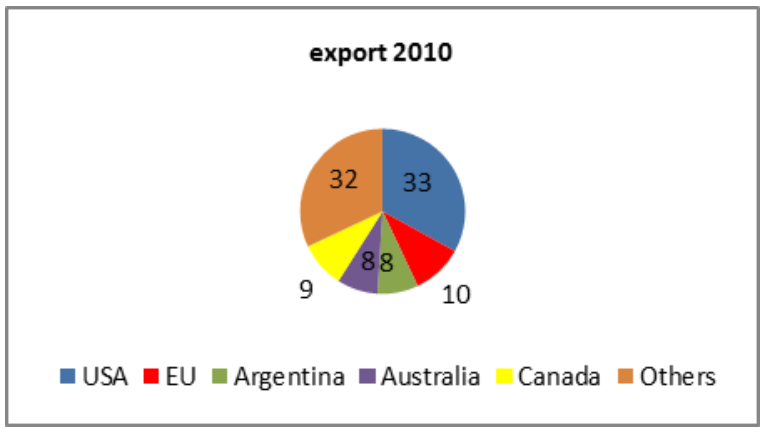

Graph 2 Geographic grain export distribution 2011

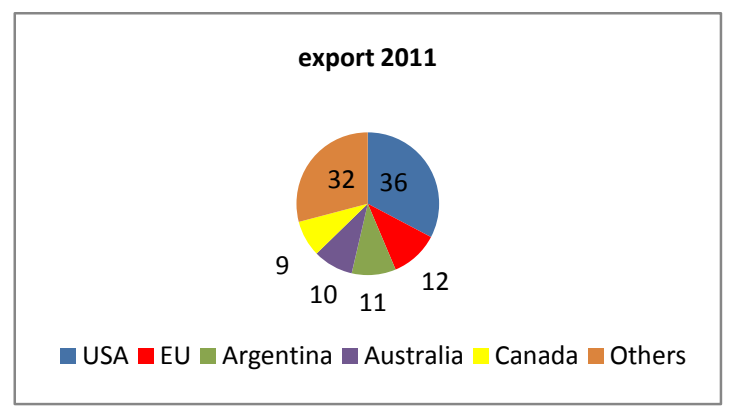

Graph 3 Geographic grain import distribution 2010

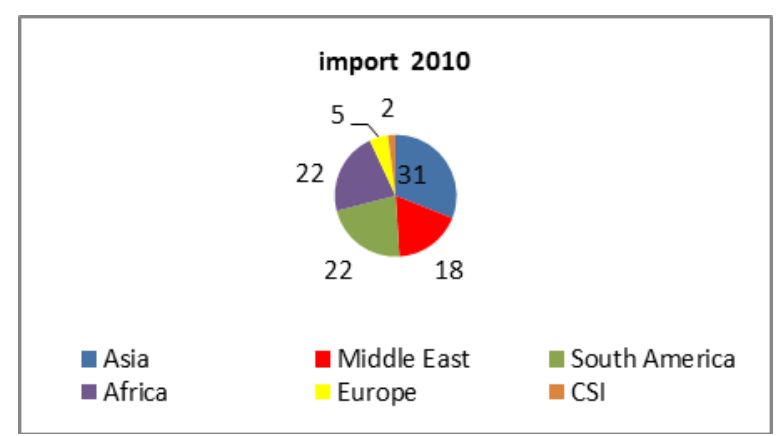

Graph 4 Geographic grain import distribution 2011

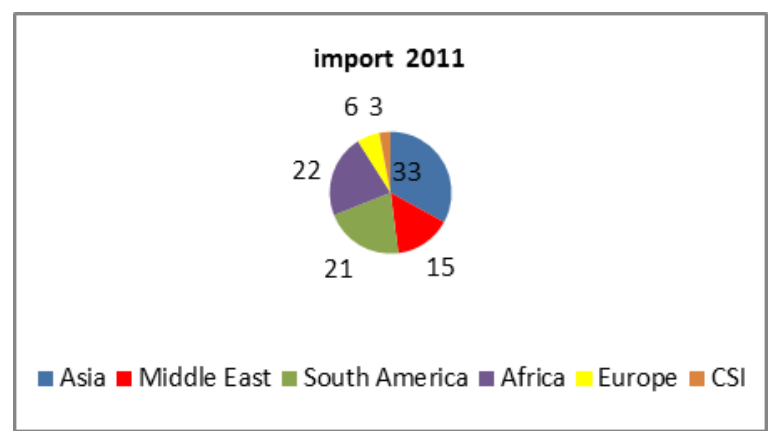

The biggest port density is registered on the Atlantic coast of North America and South America, in south of Africa and south-east and south-west coast of Australia. The most important ports with their biggest cereal terminals are presented in Table 2, which confirms the reality and what was mentioned in the paragraph before.
Table 2 Main grain ports of the world

\begin{tabular}{|c|c|}
\hline Country & Port \\
\hline \multirow{4}{*}{ USA } & Baltimore \\
\hline & Norfolk \\
\hline & New Orleans \\
\hline & Houston \\
\hline \multirow[t]{2}{*}{ France } & Rouen \\
\hline & Le Havre \\
\hline \multirow{3}{*}{$\begin{array}{l}\text { Russian } \\
\text { Federation }\end{array}$} & Novorossiysk \\
\hline & Rostov-on-Don \\
\hline & Temryuk \\
\hline \multirow[t]{3}{*}{ Ukraine } & Yuzhiy \\
\hline & Odessa \\
\hline & Nikolaev \\
\hline \multirow[t]{3}{*}{ Argentina } & Rosario \\
\hline & Buenos Aires \\
\hline & Bahia Blanc \\
\hline \multirow[t]{2}{*}{ Brazil } & Santos \\
\hline & $\begin{array}{r}\text { Rio Grande do } \\
\text { Sul }\end{array}$ \\
\hline \multirow[t]{5}{*}{ Canada } & Montreal \\
\hline & Quebec \\
\hline & Great Lakes \\
\hline & Sorel \\
\hline & Seven Islands \\
\hline \multirow[t]{5}{*}{ Australia } & Fremantle \\
\hline & Bunbury \\
\hline & Esperance \\
\hline & Adelaide \\
\hline & Portland \\
\hline Romania & Constanţa \\
\hline
\end{tabular}

For maritime transport of grain analysis it was used an economic statistic indicator which is commonly known as The roadmap of the goods or "ton/miles", and serves as a synthesis of volume transported and distance made. In this case the economic indicator tone/mile expresses the report between a ton of transported grain and a one mile distance. The value of this indicator has an indirect but important relevance on the maritime grain transport routes. For example the majority of wheat production from main producer/exporter regions can modify the flux of the commercial routes and may put an increasing pressure on transit zones.

The tone/miles indicator $(\mathrm{Pa} * \mathrm{~m})$ is the volume of carried goods and it is determined by how heavy are the goods and the distance on which are transported and it can be determined with the following equation:

$P a \cdot m=G_{1} \cdot d_{1}+G_{2} \cdot d_{2}+G_{3} \cdot d_{3}+\ldots+G_{n} \cdot d_{n}=\sum_{i=1}^{n} G_{i} \cdot d_{i}$ 
"Mircea cel Batran" Naval Academy Scientific Bulletin, Volume XX - 2017 - Issue 1 The journal is indexed in: PROQUEST / DOAJ / Crossref / EBSCOhost / INDEX COPERNICUS / DRJI / OAJI I JOURNAL INDEX I I2OR / SCIENCE LIBRARY INDEX / Google Scholar / Academic Keys/ ROAD Open Access I Academic Resources / Scientific Indexing Services / SCIPIO I JIFACTOR

where: $G_{i}$ represents the quantity of cargo expressed in tons $(\mathrm{t}) ; d_{i}$-distance made by ships with a transport until the port of destination expressed in nautical miles (nM)

\section{Results}

Grain forms a third category of good carried on the sea and represents about $10 \%$ of total dry bulk cargo commerce globally. The worldwide production of grain between $1994-2013$ is the following (table 3 and graphic 5):

Table 3 Global export of grains in $1994-2013$ period in million tons

Table 3

\begin{tabular}{|l|l|l|l|l|l|l|l|l|l|l|}
\hline Year & $\mathbf{1 9 9 4}$ & $\mathbf{1 9 9 5}$ & $\mathbf{1 9 9 6}$ & $\mathbf{1 9 9 7}$ & $\mathbf{1 9 9 8}$ & $\mathbf{1 9 9 9}$ & $\mathbf{2 0 0 0}$ & $\mathbf{2 0 0 1}$ & $\mathbf{2 0 0 2}$ & $\mathbf{2 0 0 3}$ \\
\hline $\begin{array}{l}\text { Total } \\
\begin{array}{l}\text { worldwide } \\
\text { production of } \\
\text { grain }\end{array}\end{array}$ & 103,6 & 101,6 & $\mathbf{9 8 , 8}$ & 107,0 & 109.0 & 114,4 & 117,1 & 113,7 & 120,3 & 109,5 \\
\cline { 2 - 11 } & $\mathbf{2 0 0 4}$ & $\mathbf{2 0 0 5}$ & $\mathbf{2 0 0 6}$ & $\mathbf{2 0 0 7}$ & $\mathbf{2 0 0 8}$ & $\mathbf{2 0 0 9}$ & $\mathbf{2 0 1 0}$ & $\mathbf{2 0 1 1}$ & $\mathbf{2 0 1 2}$ & $\mathbf{2 0 1 3}$ \\
\cline { 2 - 11 } & 118,9 & n.a. & 126,4 & 124,6 & 131,1 & 146,9 & 145,7 & 148,3 & 164,6 & 162,7 \\
\hline
\end{tabular}

Source: FAO - UNCTAD Statistics, accessed 10.02.2017
Graph 5 Global export of grains (1994 - 2013) in million tonnes

Graph 5

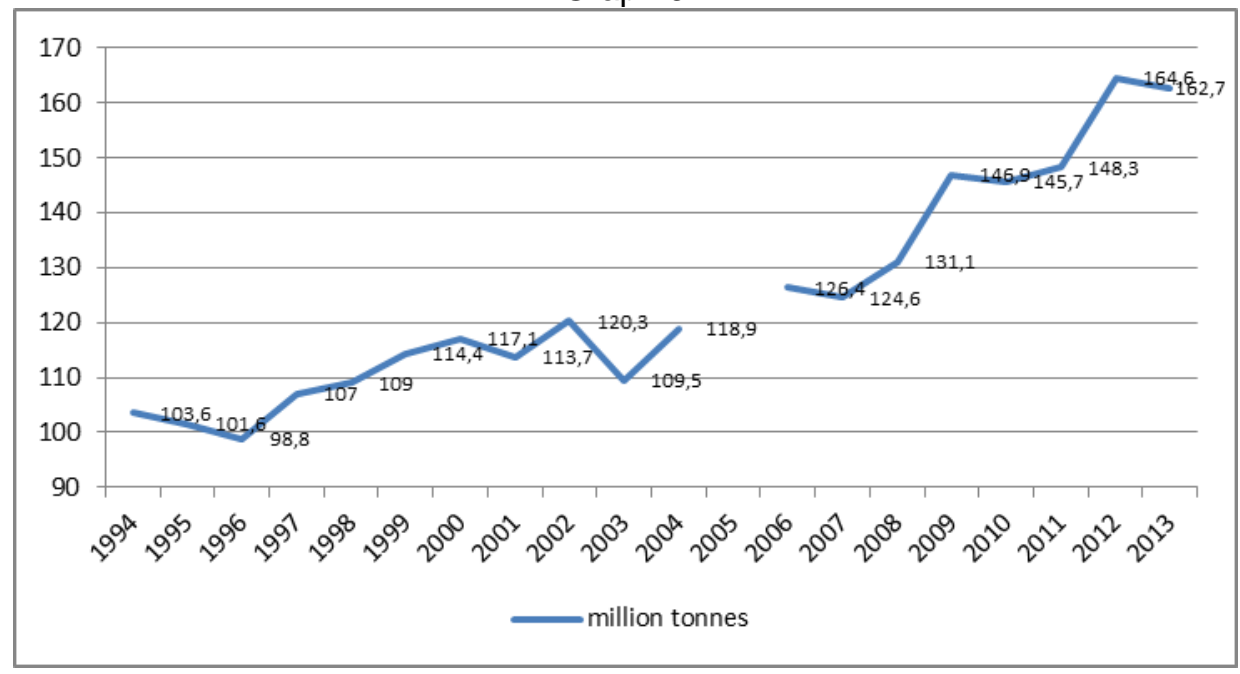

The quantity of grain shipped on the sea is about 453 million tonnes (in 2015), from which 324 million tonnes (approximately $72 \%$ ) are wheat, barley or oats or other grains and about 110 million tonnes (approximately $28 \%$ ) is soybean (table 4 and graphic 6). In year 2015 the global commerce of grains on the sea (wheat, other cereals and soybean) has reported a growth of about $+4,9 \%$ in comparison with 2014 .

Table 4 Total amount of grain transported on sea in 2009 - 2015 period, expressed in million tonnes

Table 4

\begin{tabular}{|c|c|c|c|c|c|c|c|c|}
\hline No. & Grain/year & $\mathbf{2 0 0 9}$ & $\mathbf{2 0 1 0}$ & $\mathbf{2 0 1 1}$ & $\mathbf{2 0 1 2}$ & $\mathbf{2 0 1 3}$ & $\mathbf{2 0 1 4}$ & $\mathbf{2 0 1 5}$ \\
\hline 1 & $\begin{array}{c}\text { Wheat and other } \\
\text { grains* }\end{array}$ & n.a. & n.a. & 255 & 279 & 287 & 317 & 324 \\
\hline 2 & Soybeans & n.a. & n.a. & 91 & 96 & 103 & 117 & 129 \\
\hline 3 & Total grain & 316 & 341 & 346 & 375 & 390 & 434 & 453 \\
\hline 4 & Total dry bulk cargo & 4089 & 4362 & 3841 & 4099 & 4333 & 4553 & 4569 \\
\hline 5 & $\begin{array}{c}\% \text { of cereals from total } \\
\text { dry bulk cargo }\end{array}$ & $\begin{array}{c}7,72 \\
\%\end{array}$ & $7,8 \%$ & $9,01 \%$ & $9,15 \%$ & $9,0 \%$ & $9,53 \%$ & $9,91 \%$ \\
\hline
\end{tabular}


"Mircea cel Batran" Naval Academy Scientific Bulletin, Volume XX - 2017 - Issue 1 The journal is indexed in: PROQUEST / DOAJ / Crossref / EBSCOhost / INDEX COPERNICUS / DRJI / OAJI I JOURNAL INDEX / I2OR / SCIENCE LIBRARY INDEX / Google Scholar / Academic Keys/ ROAD Open Access I Academic Resources / Scientific Indexing Services / SCIPIO / JIFACTOR

*Grain: wheat, corn, barley, oats, rye, sorghum and soya
Graphic 6 Evolution of the total volume of grain carried on the sea between $2009-2015$, expressed in million tonnes

Graph 6

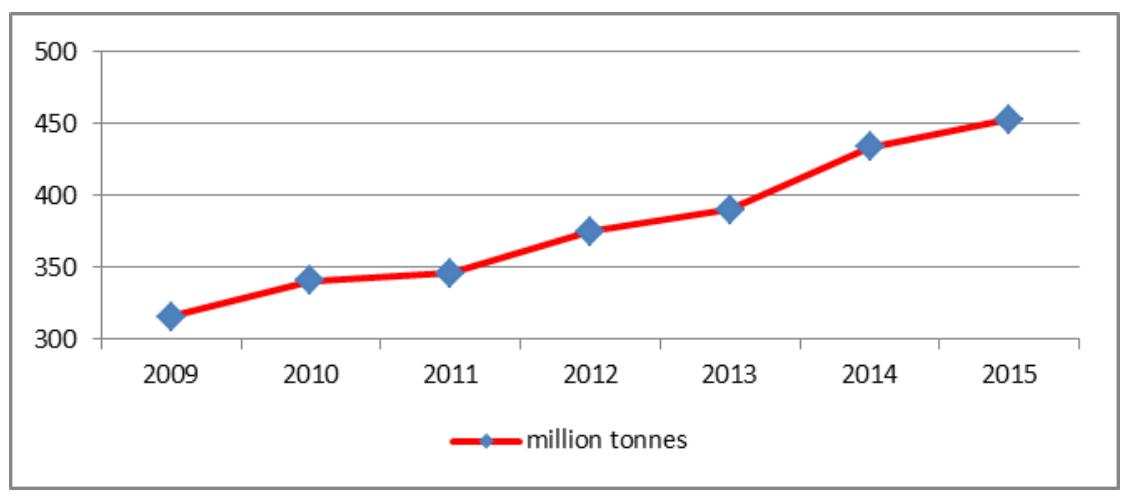

The analysis of ton/miles indicator evolution is for worldwide maritime transportation of grain in 1992 - 2012 period, expressed in billion ton/miles shows the following (tabel 5 and graph 7): the value of indicator has registered a constant growth from 1122 billion tonn-miles value in 1999, to 1940 billion ton-miles in 2012 .

Table 5 Value of tonne/mile indicator in maritime grain transport (1999 - 2012) in billion ton-miles

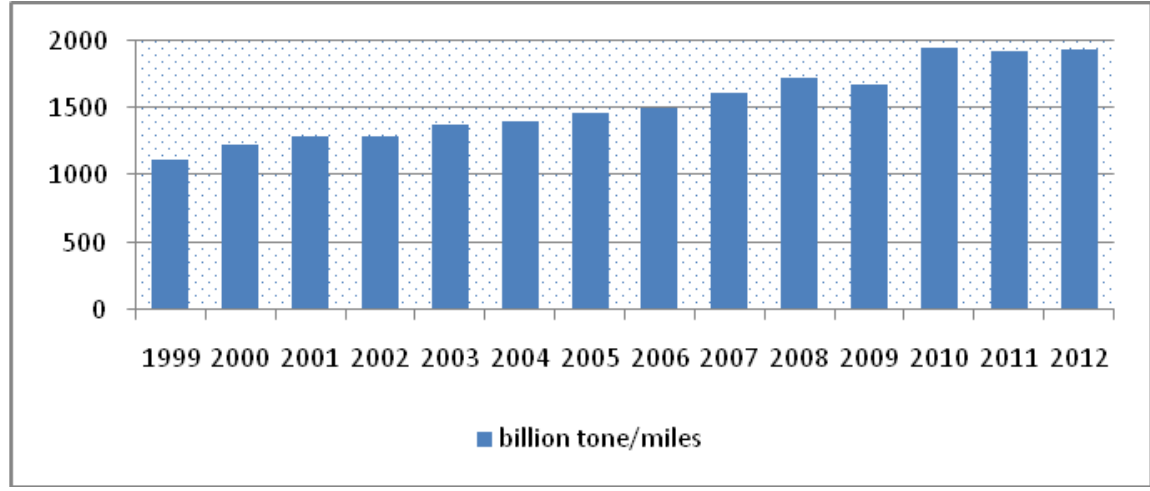

Graph 7 Evolution of tonne/mile indicator in maritime grain transport (1999 - 2012) in billion ton-miles

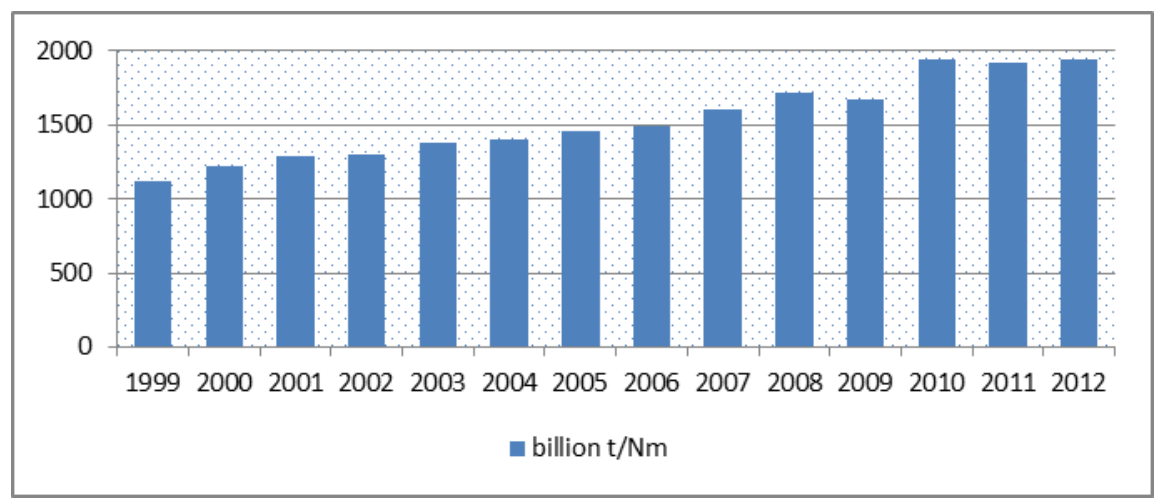

Relations determined by the frequency and intensity of commercialization flux of each exporter region based on official available data (table 6) are:
-U.S.A., the biggest grain exporter has its 107,6 million tons export distributed as it follows: 26,5 


\section{"Mircea cel Batran" Naval Academy Scientific Bulletin, Volume XX - 2017 - Issue 1 The journal is indexed in: PROQUEST I DOAJ / Crossref / EBSCOhost / INDEX COPERNICUS / DRJI / OAJI I JOURNAL INDEX I I2OR / SCIENCE LIBRARY INDEX / Google Scholar / Academic Keys/ ROAD Open Access I Academic Resources / Scientific Indexing Services / SCIPIO / JIFACTOR}

mil. $\mathrm{t}$ in North America and South America; 22,8 mil. $\mathrm{t}$ in Japan; 14,6 mil. $\mathrm{t}$ in Africa; 5 mil. $\mathrm{t}$ in Europe; 3,6 mil. t in Near East; 2,8 mil. $t$ in Gulf area;

-Canada export figures (15,7 million tons) are: North America and South America (3,2 mil. t); Africa (2,2 mil. t); Europe (1,8 mil. t); Japan (1,7 mil. t); Gulf area (0,7 mil. t); Indian Ocean region (0,8 million tons);
-South America export figures are: Europe $(8,9$ million tons); America (7,8 mil. t); Africa (7,4 mil. t); Gulf area (6,0 mil. t); Indian Ocean region (4,7 mil. t), etc.;

-Australia export figures are: Indian Ocean region (6,7 mil. t); Africa (3,8 mil. t); Japan (2,7 mil. t), etc.

Table 6 Quantity of grain shipped between different regions on Earth, in million metric-tone

Table 6

\begin{tabular}{|l|c|c|c|c|c|c|c|}
\hline \multirow{2}{*}{ Fo } & \multirow{2}{*}{ USA } & \multirow{2}{*}{$\begin{array}{c}\text { Canad } \\
\mathrm{a}\end{array}$} & $\begin{array}{c}\text { South } \\
\text { America }\end{array}$ & Australia & \multirow{2}{*}{ Others } & \multicolumn{2}{c|}{ Total } \\
\cline { 5 - 8 } & & & & & & mil.t. & $\%$ \\
\hline Gulf/Continent & 2,8 & 0,7 & 6,0 & 0,0 & 0,3 & 9,8 & $4 \%$ \\
\hline Europe & 5,0 & 1,8 & 8,9 & 0,7 & 7,4 & 23,9 & $10 \%$ \\
\hline Africa & 14,6 & 2,2 & 7,4 & 3,8 & 12,0 & 40,1 & $17 \%$ \\
\hline America & 26,5 & 3,2 & 7,8 & 0,2 & 0,2 & 37,9 & $16 \%$ \\
\hline Near East & 3,6 & - & 1,0 & 0,1 & 2,9 & 7,6 & $3 \%$ \\
\hline Indian Ocean region & 2,1 & 0,8 & 4,7 & 6,7 & 5,0 & 19,2 & $8 \%$ \\
\hline Japan & 22,8 & 1,7 & 0,8 & 2,7 & 0,7 & 28,6 & $12 \%$ \\
\hline Others & 30,1 & 5,2 & 16,4 & 9,9 & 6,7 & 68,4 & $29 \%$ \\
\hline Others unspecified & - & - & - & 0,5 & - & 0,5 & $0 \%$ \\
\hline Total & 107,6 & 15,7 & 53,0 & 24,6 & 35,1 & 236,0 & $100 \%$ \\
\hline$\%$ total & $46 \%$ & $7 \%$ & $22 \%$ & $10 \%$ & $15 \%$ & $100 \%$ & \\
\hline
\end{tabular}

Source: Fearnlyes Review, different editions

Synthesis indicator variations have something in common equally for grains importers or exporters regions and that is some influential factors: the particularities of pedo-climatic zones which are affected by global warming; particularities of regional and national agriculture strategies; particularities of supply and demand on a market etc. But not only the quantity of goods demanded for shipment is taken into consideration by shipowners when they want to enter on grains market shipment.

This type of grain transport is attractive for shipowners because of the following facts (Lun et at, 2010):

-major investments are not required in time because this market is not well developed yet and also the facilities offered by competition are similar;

-access to information regarding freight and possible partners is facilitated by different companies where shipowners can adhere and an example is Baltic Dry Index (except broker companies);

-big capital investment is necessary only when ships are acquired and this thing can be a setback for those who want to enter the market. On the other hand companies with a solid business plan on this segment can obtain a lot easier financing from the banks compared to those who have activities on other markets: it is important to note that on entering the market there aren't other investments besides the initial ones;

-legal framework of this type of commerce and grains transport is not as tough as other specialized vessels (for e.g.: tankers, passenger ships, container ships);

-in terms of legislation if a shipowner wants to exit this market it is not so difficult. For example, a big company which will leave grains market will not affect so much the freight because in the majority of cases ships are sold on the second-hand market to other shipowner. By doing this the tonnage supply will also not be affected so much; -activity on this segment does not require an implementation of a complex marketing policy or making a more attractive offer package in comparison with liner shipping services or containerized shipping services.

Because it's specific and complexity the grain shipment had an impact on structuring and modernization processes of maritime transport segment. 


\author{
"Mircea cel Batran" Naval Academy Scientific Bulletin, Volume XX - 2017 - Issue 1 \\ The journal is indexed in: PROQUEST / DOAJ / Crossref / EBSCOhost / INDEX COPERNICUS / DRJI / OAJI I \\ JOURNAL INDEX I I2OR / SCIENCE LIBRARY INDEX / Google Scholar / Academic Keys/ ROAD Open Access I \\ Academic Resources / Scientific Indexing Services / SCIPIO / JIFACTOR
}

\title{
Conclusion
}

First of all, performances achieved on grains maritime transport are influenced by ships demand and cargo supply. These are in a relation that defines the characteristics of the market regarding structure, number of shipping companies, the magnitude of operations and fleet number. Different studies made on this subject concluded that the activity on this market can be considered a "perfect competition" (Lun et al, 2010)

As it was mentioned before, the economic climate of bulk cargo market and grains market is generated by a combined evolution of the other four markets. Basically a trend on the economic market is based on the financial fluxes that enters and exits into it.

In this case the main financial flux entry is composed of an added value obtained from freight payments of transport services offered. Determining level of freight as a value makes the shipowners to make developing strategies of their fleet. On the other hand, if the freight value is low they can decide to retreat the fleet from the market for a period or they can shut down the activity if they don't have profit.

Grain commerce is a seasonal activity that is influenced by harvesting period. Generally speaking this period is from August to September in U.S.A., European countries, Canada, Russian Federation and Ukraine. The winter wheat is harvested until July in United States of America, Canada and Europe. In Australia harvesting period is usually from October to January. For Argentina, wheat harvesting period is December - January, corn harvesting January - April and for soybeans March - June. As a conclusion we can see that the main export period is from December until June.

Another conclusion related to harvest period is that it is correlated to peak period regarding demand for grains maritime transport. An example of a classic route is South America - Asia, which is a long route that takes almost three months to make it back and forth, but it is a good thing considering the fact that in harvest period the grains transportation expressed in tones-miles is high. To gain a leverage some shipowners move their ships in South America ports before beginning of harvest period in order to get a good freight and better grains. Also due to fact that most exporter countries are situated in Atlantic Ocean basin, this market has an economic advantage over Pacific Ocean basin.

Grains have specific loading - unloading operations, from automatized, mechanized to manual ones. In the main loading grains ports, these are transported to their terminals by trains, cars or barges. Evolved countries have local pick-up points network. These are connected to grains terminals by railways, motorways or local water routes and the cargo is deposited in silos and other auxiliary spaces if grains quantities exceed. Another main characteristic of loading and unloading grains operations is the impact of meteorological conditions because grains are sensible to precipitations and humidity and because of this issue there are some specified conditions stipulated in grain transport contract such as influence of bad weather to handling and cargo shipment that affect the freight and necessary time of journey and loadingunloading operations.

Freight value is determined by available grains quantities for shipment and by number of vessels that comply with the requirements for each contract, depending on the route and available time. For example when in Australia there are drought periods that affect the grains culture, importers from China or Far East must look after supplies in North America or Canada. The same thing is available for grain imports in South America in detriment of the ones in North America for Europe or Asia. In both cases a change of route implies greater distances and this means that ships have longer contracts and bigger freight values.

An essential piece in making maritime grains transport strategies by shipowners is the quantity of grains shipped and the time necessary for doing this between the main two regions - exporters and importers.

Shipowners are making strategies that have a clear objective and that is to acquire as much quantity as they can for a shipment, based on grains production analysis and it's forecast evolution.

Another financial exit flux is the one generated by construction of new ships, that requires shipowners investments. This decision to have a better fleet is sustained by a good situation registered on freight market and by a smaller available fleet for transport. The strategies that develops fleets are based on freight gain forecast and on the structure of fleet depending on how old is a ship. In many cases when freight value rise the price per tonne built also rises. This fact makes a shipowner to invest in vessels construction when the price is optimum.

When goods supply is at a low level, shipowners decide to sell uncompetitive ships. During difficult times selling ships to recycling shipyards has a positive effect on freight because the total available tonnage is reduced. Money gained from these sales represents an entry into market flux.

The decision to take ships to scrap is not the best one because sometimes the price offered per tone is not satisfying. Taken into consideration that a bulk carrier has a "life" of $15-20$ years and the market doesn't have optimum conditions one may consider as a solution to sell a ship on second-hand market in order to 


\section{"Mircea cel Batran" Naval Academy Scientific Bulletin, Volume XX - 2017 - Issue 1 \\ The journal is indexed in: PROQUEST / DOAJ / Crossref / EBSCOhost / INDEX COPERNICUS I DRJI / OAJI I \\ JOURNAL INDEX I I2OR / SCIENCE LIBRARY INDEX / Google Scholar / Academic Keys/ ROAD Open Access I Academic Resources / Scientific Indexing Services / SCIPIO / JIFACTOR}

make more profit than scraping. The highest price that can be attained is when freight value is up and also the demand of second-hand ships is high. But one most think about that meeting these conditions can take a long time. Another efficient solution is to relocate ships to other specialized companies that have better or can obtain better contracts. Usually these companies need more transport capacity but they don't have enough capital to make new ones or they don't want to buy other vessels.

Analysis of tone-mile shows that a medium or small sized vessel can achieve a satisfying roadmap with many journeys on medium or small distances; for long journeys it's more profitable to have big-sized ships with higher speeds which are also fuel efficient.

Formulating some feasible strategies for making an optimized and efficient maritime grains transport one must know the main exporters and importers regions for this type of market. In other words it is made a reference to statistical analysis that are related to timeline evolution of grains production which facilitates the forecast evolution of the entire maritime transport that is analyzed.

Basically the freight value and the volume of shipped goods are directly proportional with available tonnage on the market. Shipping companies are also responsible for fleet management, tonnage supply and depends on available information about current market state and how will evolve. The profit is made only when the company can deliver the shipment and there are enough grains.

Optimum conditions can determine a shipowner to invest in shipbuilding or can make him buy second-hand vessels in order to have more tonnage available or, in other terms, they can transport more grains. On the other hand when conditions on the market are not favorable a shipowner must reduce the costs by taking out of order underperforming ships (put them to conservation, sell them on second-hand market or take them to scrap).

\section{Bibliography}

[1] Bibicescu, Gh.,1983. Transportul de mărfuri pe mare în comerţul international, Editura Sport Turism, Bucureşti (in Romanian);

[2] Bordânc V. A., 2015, Managementul transportului maritim de cereale pe ruta America-Europa. Evoluţie şi perspective, Disertaţie, Academia Navala Mircea cel Batran, Constanţa (in Romanian);

[3] Boşneagu, R., 2017, Geoeconomia transporturilor maritime, Editura EX PONTO, Constanţa (in Romanian);

[4] Boşneagu, R.,2017, Region. Regionalization. Globalization. The Sea - Territory of Globalization, $4^{\text {th }}$ Edition, The International Scientific Conference, Communication, Context, Interdisciplinarity, Petru Maior University of Tîrgu Mureş, www.upm.ro/cci/CCl-04/vol04-Spi.pdfh;

[5] Boşneagu, R., 2016, International Relations Development Strategies from the Perspective of Maritime Freight Transport Development, Constanta Maritime University Annals, Year XVI, Vol.25, 2016, http://www2.cmu-edu.eu/anale/wp-content/uploads/sites/10/2016/10/Anale-vol.25-2016.pdf;

[6] Boşneagu, R., et al., 2014, Strategic research of the maritime market, The 8th edition of the International Conference on European Integration - Realities and Perspectives, Danubius University of Galaţi, 2013, http://www.conferences.univ-danubius.ro/index.php/EIRP/EIRP 2013;

[7] Boşneagu, R., et al., 2014, World economy and world seaborne trade in the 2005 -2013 period, The 9th edition of the International Conference on European Integration - Realities and Perspectives, Danubius University of Galaţi, http://www.conferences.univ-danubius.ro/index. Php /EIRP /EIRP2014;

[8] Lorange P., 2005,Shipping company strategies. Global management under turbulent conditions. Elsevier;

[9] Lun Y., et al., 2010, Shipping and Logistics Management, Springer, New York;

[10] Stopford, M., 2009, Maritime economics, Routledge, London \& New York;

[11] Mercier St.,1999, The Evolution of World Grain Trade, Review of Agricultural Economics, Blackwell Publishing on the behalf of Agricultural Applied Economics Association, Cambridge;

[12] Stan, V., A., 2006, Tratat de transport maritim. Editura Universul Familiei, Bucureşti (in Romanian);

$[13]^{\star \star \star} \mathrm{http} / / \mathrm{www}$. unctad.org/statictics;

$[14]^{\star \star \star}$ http/www.igc.org/statistics;

$[15]^{\star \star \star}$ Statistical Pocketbook, World food and agriculture, 2015, Food and Agriculture - OUN;

[16] ${ }^{\star \star \star}$ The State of Agriculturel Commodity Markets, 2015-2016, Food and Agriculture Organization of

United Nations;

[17] $]^{\star \star \star}$ Review of Maritime Review, 2015, UNCTAD;

[18] ${ }^{\star \star \star}$ Review of Maritime Review, 2016, UNCTAD;

[19] ${ }^{\star \star *}$ Trade and Development Report, 2015, UNCTAD;

[20]*** Trade and Development Report, 2016, UNCTAD;

[21] ${ }^{\star \star \star}$ World Investment Report, 2015, UNCTAD;

[22] ${ }^{\star \star \star}$ World Investment Report, 2016, UNCTAD;

[23] ${ }^{\star \star \star}$ Fearleyns Reports, 2005/2015 issues;

(c) 2017. This work is licensed under the Creative Commons Attribution-Noncommercial-Share Alike 4.0 License. 
"Mircea cel Batran" Naval Academy Scientific Bulletin, Volume XX - 2017 - Issue 1 The journal is indexed in: PROQUEST / DOAJ / Crossref / EBSCOhost / INDEX COPERNICUS / DRJI / OAJI I JOURNAL INDEX I I2OR / SCIENCE LIBRARY INDEX / Google Scholar / Academic Keys/ ROAD Open Access I Academic Resources / Scientific Indexing Services / SCIPIO / JIFACTOR

[24]*** AMIS Crops: Market Situation and Outlook in 2013/14, International Grains Council, Amy Reynolds International Grains Council, areynolds@igc.int;

[25] ${ }^{\star \star *}$ Grain Market Report 473/2017, INTERNATIONAL GRAINS COUNCIL, www.igc.int. 